\title{
Fabrication, Inspection, and Test Plan for the Advanced Test Reactor (ATR) Mixed-Oxide (MOX) Fuel Irradiation Project
}

Published November 1997

Idaho National Engineering and Environmental Laboratory Lockheed Martin Idaho Technologies Company

Idaho Falls, Idaho 83415

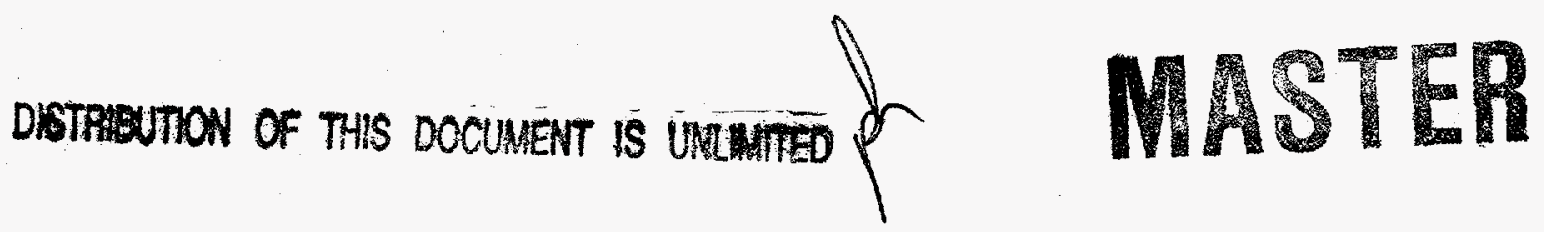

Prepared for the

U.S. Department of Energy

Office of Fissile Materials Disposition

Under DOE Idaho Operations Office

Contract DE-AC07-94ID13223 


\section{DISCLAIMER}

This report was prepared as an account of work sponsored by an agency of the United States Government. Neither the United States Government nor any agency thereof, nor any of their employees, makes any warranty, express or implied, or assumes any legal liability or responsibility for the accuracy, completeness, or usefulness of any information, apparatus, product, or process disclosed, or represents that its use would not infringe privately owned rights. Reference herein to any specific commercial product, process, or service by trade name, trademark, manufacturer, or otherwise does not necessarily constitute or imply its endorsement, recommendation, or favoring by the United States Government or any agency thereof. The views and opinions of authors expressed herein do not necessarily state or reflect those of the United States Government or any agency thereof. 


\section{DISCLAIMER}

Portions of this document may be illegible electronic image products. Images are produced from the best available original document. 


\title{
Fabrication, Inspection, and Test Plan for the Advanced Test Reactor (ATR) Mixed-Oxide (MOX) Fuel Irradiation Project
}

\author{
Revision 0
}

Approved by:

J. M.Ryskamp

INEEL MOX Fuel Irradiation Project Manager/LMITCO
$11 / 3 / 97$

Date

Concurred by:

S. A. Hodge per telephone conference

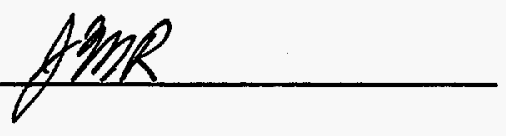

S. A. Hodge

$10 / 29 / 97$ MOX Project Manager/ORNL

Date 


\section{SUMMARY}

The Department of Energy (DOE) Fissile Materials Disposition Program (FMDP) has announced that reactor irradiation of Mixed-Oxide (MOX) fuel is one of the preferred alternatives for disposal of surplus weapons-usable plutonium $(\mathrm{Pu})$. MOX fuel has been utilized domestically in test reactors and on an experimental basis in a number of Commercial Light Water Reactors (CLWRs). Most of this experience has been with $\mathrm{Pu}$ derived from spent low enriched uranium (LEU) fuel, known as reactor grade (RG) $\mathrm{Pu}$. The MOX fuel test will be irradiated in the ATR to provide preliminary data to demonstrate that the unique properties of surplus weapons-derived or weapons-grade (WG) plutonium ( $\mathrm{Pu}$ ) do not compromise the applicability of this MOX experience base. In addition, the test will contribute experience with irradiation of gallium-containing fuel to the data base required for resolution of generic CLWR fuel design issues (ORNL/MD/LTR-76).

Oak Ridge National Laboratory (ORNL), acting as an agent for the Department of Energy Office of Fissile Materials Disposition (DOE-MD), leads the Test Project Office. Los Alamos National Laboratory (LANL) will supply the sealed fuel pin assemblies to the Idaho National Engineering and Environmental Laboratory (INEEL). The INEEL will assemble the capsules from hardware supplied by ORNL and will load the fuel pins into the capsules. The test assembly will contain nine capsule assemblies containing various fuel types as described in the Light Water Reactor Mixed Oxide Fuel Irradiation Test Project Plan, (ORNL/MD/LTR-78). Each fuel pin will be contained within a stainless steel capsule and placed in a 3 hole I-Basket with three capsule assemblies per hole. The loaded basket, as the test assembly, will then be loaded into the ATR in reactor irradiation position I-24. This Fabrication, Inspection, and Test Plan (FITP) for the INEEL Advanced Test Reactor (ATR) Mixed-Oxide (MOX) Fuel Irradiation Project describes the procedural approach for the fuel pin receipt, capsule fabrication (welding), capsule inspection, capsule loading into the basket, neutron dosimetry preparation, insertion into the ATR, irradiation, and removal into the ATR canal. 


\section{CONTENTS}

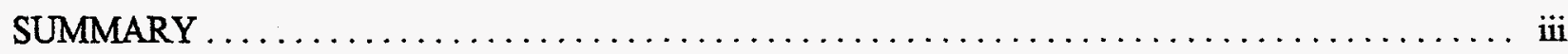

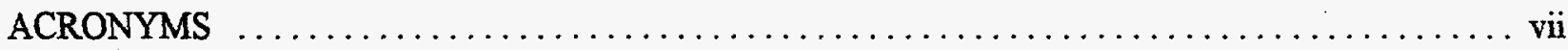

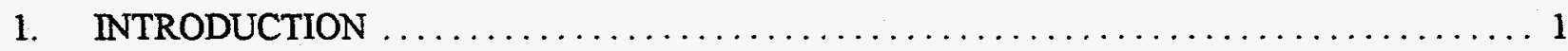

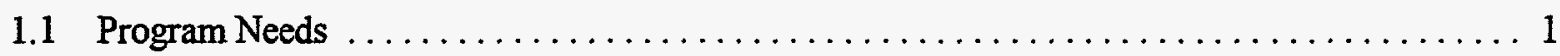

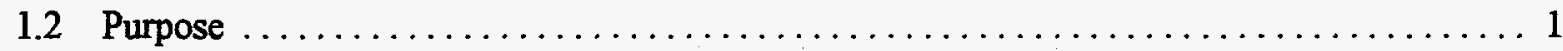

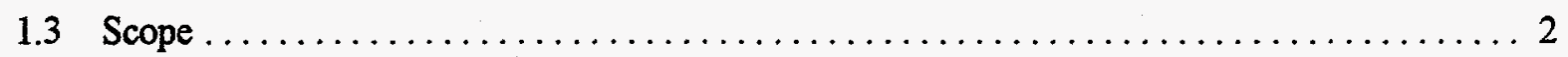

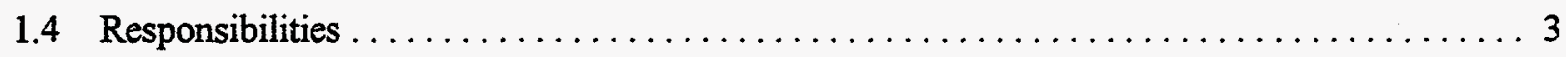

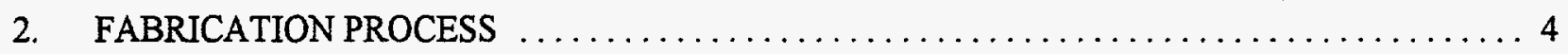

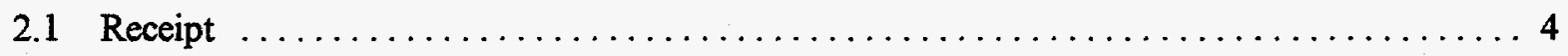

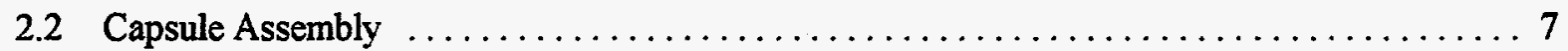

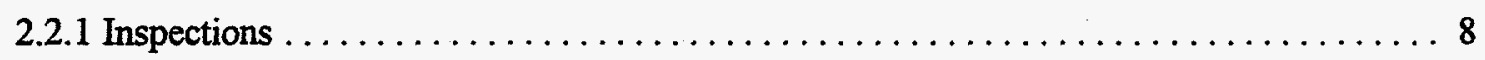

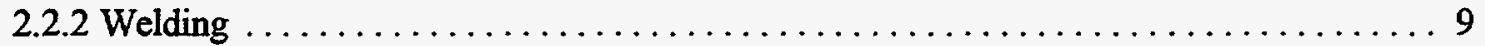

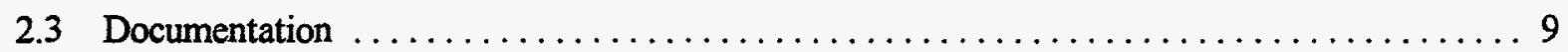

3. REACTOR INSERTION AND REMOVAL $\ldots \ldots \ldots \ldots \ldots \ldots \ldots \ldots \ldots \ldots \ldots \ldots \ldots \ldots$

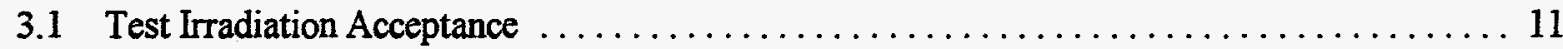

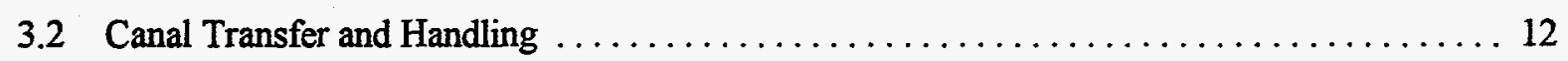

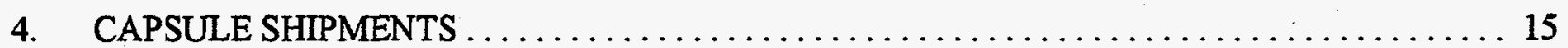

4.1 ORNL Unirradiated Archive Capsule Assemblies $\ldots \ldots \ldots \ldots \ldots \ldots \ldots \ldots \ldots \ldots \ldots$

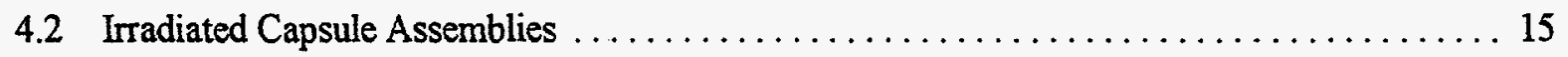

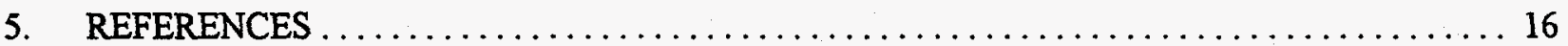

\section{FIGURES}

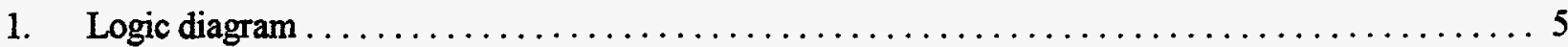


2. ATR core cross-section diagram 


\section{ACRONYMS}

ATR Advanced Test Reactor

CLWR Commercial Light Water Reactor

CRD Cycle Reference Document

DOP Detailed Operating Procedure

ESA Experiment Safety Analysis

FCF Facility Change Form

FITP Fabrication, Inspection and Test Plan

FMDP Fissile Materials Disposition Program

GE General Electric

GWD/MT Gigawatt days per metric ton

INEEL Idaho National Engineering and Environmental Laboratory

LANL Los Alamos National Laboratory

LMICO Lockheed Martin Idaho Technologies Company

MBA Material Balance Area

MOX Mixed Oxide

OMM Operating \& Maintenance Manual

ORNL Oak Ridge National Laboratory

OSCC Outer Shim Control Cylinders

PIE Post-Irradiation Examination

ppm Parts Per Million

QA Quality Assurance

RDAS Reactor Data Acquisition System 
RG Reactor Grade

RML Radiation Measurements Laboratory

SAR Safety Analysis Report

SD Standing Directive

SP Standard Practice

SORC Safety Oversite Review Committee

TRA Test Reactor Area

TSR Technical Safety Recuirements

USQ Unreviewed Safety Cuestion

WG Weapons Grade 


\section{Fabrication, Inspection, and Test Plan for the Advanced Test Reactor (ATR) Mixed-Oxide (MOX) Fuel Irradiation Project}

\section{INTRODUCTION}

The Department of Energy (DOE) Fissile Materials Disposition Program (FMDP) has announced that reactor irradiation of MOX fuel is one of the preferred alternatives for disposal of surplus weapons-usable plutonium $(\mathrm{Pu})$. MOX fuel has been utilized domestically in test reactors and on an experimental basis in a number of Commercial Light Water Reactors (CLWRs). Most of this experience has been with Pu derived from spent low enriched uranium (LEU) fuel, known as reactor grade (RG) $\mathrm{Pu}$. The MOX fuel test will be irradiated in the ATR to provide preliminary data to demonstrate that the unique properties of surplus weapons-derived or weapons-grade (WG) plutonium $(\mathrm{Pu})$ do not compromise the applicability of this MOX experience base. In addition, the test will contribute experience with irradiation of gallium-containing fuel to the data base required for resolution of generic CLWR fuel design issues (ORNL/MD/LTR-76). This Fabrication, Inspection, and Test Plan (FITP) is a level 2 document as defined in the FMDP LWR MOX Fuel Irradiation Test Project Plan (ORNL/MD/LTR-78).

\subsection{Program Needs}

The primary focus of the irradiation test is to address outstanding technical issues for the deployment of MOX fuel cycles in CLWRs using weapons-derived plutonium. By performing this irradiation test, the FMDP will demonstrate the ability to manufacture the WG MOX experiment, ship the unirradiated experiment, irradiate the experiment, ship the irradiated experiment, and perform post-irradiation examination (PIE) on the experiment. The LWR MOX fuel irradiation test will irradiate MOX fuel produced in the Technical Area-55 (TA-55) facility at Los Alamos National Laboratory (LANL). Two types of MOX fuel will be irradiated to investigate some unresolved generic fuel development/qualification issues. The uninstrumented test assembly (no on-line continuous measurements) will be inserted in the ATR for irradiation. PIE will be performed in the Irradiated Fuels Examination Laboratory at Oak Ridge National Laboratory (ORNL). Further information about the entire project is contained in the FMDP LWR MOX Fuel Irradiation Test Project Plan (ORNL/MD/LTR-78) maintained by ORNL.

\subsection{Purpose}

The purpose of this Fabrication, Inspection, and Test Plan (FITP) for the Idaho National Engineering and Environmental Laboratory (INEEL) Advanced Test Reactor (ATR) Mixed-Oxide (MOX) Fuel Irradiation Project is to describe the documented approach for the assembly, loading, welding, inspection, and testing for the irradiation of MOX fuel in the ATR. This FITP provides the sequence of operations to be utilized in fuel pin receipt, capsule fabrication (welding), capsule inspection, capsule loading into a basket, neutron dosimetry preparation, insertion into ATR, irradiation, and removal into the ATR canal either by procedural reference or by direct incorporation for all aspects of this fabrication campaign from receipt inspection through shipment of the irradiated capsules to ORNL. 


\subsection{Scope}

All INEEL activities will be conducted according to prescribed quality standards. An effective quality assurance program will be implemented and maintained, consistent with Title 10 Code of Federal Regulations, Part 830.120, Quclity Assurance Requirements. In response to 10 CFR 830.120, Lockheed Martin Idaho Technologies Company (LMITCO), the primary contractor at the INEEL, has developed and received DOE approval of a Quality Assurance Program Document (QAPD), Program Requirements Document, PRD-101. ORNL has directed the use of the applicable portions of 10 CFR 830.120 , Quality Assurance Requirements, as the baseline requirements document for developing and implementing quality assurance programs. Each of the activities have been evaluated to ensure appropriate QA requirements are applied. The test hardware nomenclature used throughout this document is consistent with that adopted by the project:

- Fuel pellet-individual pieces of ceramic MOX fuel

- Fuel pin assembly_Zircaloy tube with end caps containing a stack of 15 fuel pellets and a spring

- Capsule assembly - $\quad$ tainless steel tube with end caps containing a fuel pin assembly

- Basket assembly-aluminum insert for the ATR I-hole with attached neutron shield

- Test assembly - basket assembly with up to nine capsule assemblies and neutron dosimetry.

Each capsule assembly consists of a stainless steel tube with end caps containing a fuel pin assembly fabricated by LANL. Each fuel pin assembly contains a stack of 15 fuel pellets within a zircaloy tube and end caps. Each fabricated fuel pin assembly will have a spring at the top to maintain the fuel pellet stack configuration. INEEL will insert the fuel pin assemblies and complete the required seal weld on each capsule assembly using a qualified weld procedure. The capsule assemblies will be loaded into the basket assembly at the INEEL with attached neutron shield and neutron dosimetry. The overall test assembly consists of the basket assembly with up to nine capsule assemblies and neutron dosimetry.

Upon completion of the welding and inspection, the capsule assemblies will be loaded into the basket assembly in accordance with the referenced loading pattern described in the ATR Capsule Assembly Loading and Operation Schedule, ORNL/MD/LTR-91, September 1997. The test assembly will contain the fuel pins containing various fuel types as described in the Light Water Reactor Mixed Oxide Fuel Irradiation Test Project Plan (ORNL/MD/LTR-i/8). Each fuel pin assembly will be contained within a stainless steel capsule and placed in a 3 hole I-Basket (X2E801214A002) supplied by ORNL, with three capsule assemblies per hole. The test assemblies will be irradiated in the ATR for up to three (3) years, then transported to ORNL for postirradiation examination.

The INEEL will load the I-Hole basket assembly with the capsule assemblies and neutron dosimetry to complete the test assembly. The configuration of the overall test assembly is provided in the Purchase Order: Mixed-Oxide Capsule Assembly: ORNL/MD/LTR-90. 


\subsection{Responsibilities}

Programmatic organization responsibilities are depicted in the Light Water Reactor Mixed Oxide Fuel Irradiation Test Project Plan (ORNL/MD/LTR-78). The ATR MOX fuel irradiation project manager is responsible for ensuring all aspects of the project are completed as required under the Purchase Order: Mixed-Oxide Capsule Assembly: ORNL/MD/LTR-90 and the MOX fuel testing work package 81R400400.

Activities described in this FITP document are the responsibility of the INEEL ATR MOX fuel irradiation project manager; however, the project manager delegates activities to supporting organizations throughout LMITCO. Interface with LMITCO internal organizations will be required throughout the project. These internal organizations include: Reactor Operations, Radiation Control, Quality Assurance, Safeguard and Security, Transportation and Packaging and others.

The capsule assembly fabrication will be performed at the TRA Hot Cell by MAC Isotopes. Fabrication and inspection activities performed in the TRA Hot Cell will be under direct control of the LMITCO Quality Assurance Program, radiation control, and safety controls.

Once the basket assembly is inserted into the reactor, the project manager will coordinate all removal and re-insertion efforts through reactor operations personnel. Transportation of the irradiated capsule assemblies will be supported through a transportation subject matter expert, who will provide appropriate shipping documentation to complete the transportation off-site. Additional support will be provided as needed by LMITCO Applied Engineering and Development Laboratory (AEDL) engineering staff. The Project Management Plan for the INEEL Portion of the Mixed Oxide Fuel Irradiation Test Project, PLN194, issued in March 1997, depicts these responsibilities. 


\section{FABRICATION PROCESS}

ORNL, acting as an agent for the Department of Energy Office of Fissile Materials Disposition (DOEMD), leads the Test Project Office. LANL will fabricate and supply the sealed fuel pin assemblies and ORNL will fabricate and supply the capsule assembly hardware. The INEEL will complete the capsule assembly by loading, welding, and inspection in accordance with the requirements outlined in the Purchase Order: Mixed-Oxide Capsule Assembly: ORNL/MD/LTR-90, the Design, Functional, and Operational Requirements for the Advanced Test Reactor Mixed Fuel Irradiation Experiment: ORNL/MD/LTR-76, and the requirements specified on engineering drawings (X2E801214A010; ATR Capsule Assembly, X2E801214A011: ATR Capsule Body, X2E801214A012: Capsule Outer Tube, X2E801212A013: Capsule Bottom End Cap. X2E801212A015: Capsule Top End cap). As the supplier, INEEL will assemble and deliver 13 capsule assemblies: nine (9) that are required to fill the basket assembly for the initial irradiation period; two (2) replacements for insertion during the second irradiation period; and two (2) unirradiated archives that are to be shipped to ORNL following the initial test assembly insertion.

Under the activities associated with fabrication, a statement of work will be supplied to the TRA Hot Cell manager. The statement of work will require the TRA Hot Cell to develop work releases to accomplish the majority of the capsule and test assembly activities. All activities associated with the fabrication and testing of the test assembly will be under the cognizance of the LMITCO QA Program, radiation control and safety controls. The TRA Hot Cell will be supplied with all items needed for fabrication including: the detailed inventories of MOX pins, glove box assembly, detailed drawings, welding procedure and equipment, neutron dosimetry and holder with installation directions, welding mockup, MOX fuel pin assemblies, basket assembly, capsule tubing, the Purchase Order: Mixed-Oxide Capsule Assembly: ORNL/MD/LTR-90, Fresh Fuel Shipment Plan, ORNL/ML/LTR-87, and Light Water Reactor Mixed Oxide Fuel Irradiation Test Project Plan, ORNL/MD/LTR-78. In addition, quality inspection and QA support, radiation control support personnel, and safety support personnel will be made available.

A logic diagram is provided to depict the overall process for fabrication/assembly through reactor insertion acceptance. Although this logic diagram provides additional steps well beyond the purpose of this document, meeting these internal LMITCO requirements is necessary to ensure acceptance for insertion into the reactor. The details of this acceptance process are briefly discussed in this document. Specified procedures for each fabrication process will be provided to the Test Project Office for review, upon request.

\subsection{Receipt}

Fabricated hardware and fuel pins will be received at the TRA Hot Cell. Prior to commencement of new programmatic operations to be performed at the TRA Hot Cell, an Experimental Safety Analysis (TRA Hot Cell ESA) will be required. 'The ESA will ensure compliance with facility Safety Analysis Report (SAR) and Technical Surveillance Requirements (TSR), engineering controls, and environmental waste restrictions (TRA Hot Cell Experiments Safety Analysis Requirements, Standing Directive 21.1.5). In addition, prior to receiving the fuel pins, the TRA Hot Cell will be required to address, as part of the ESA, an Unreviewed Safety Questions (USQ) evaluation, (Unreviewed Safety Questions, Standard Practice 10.3.1.26). 


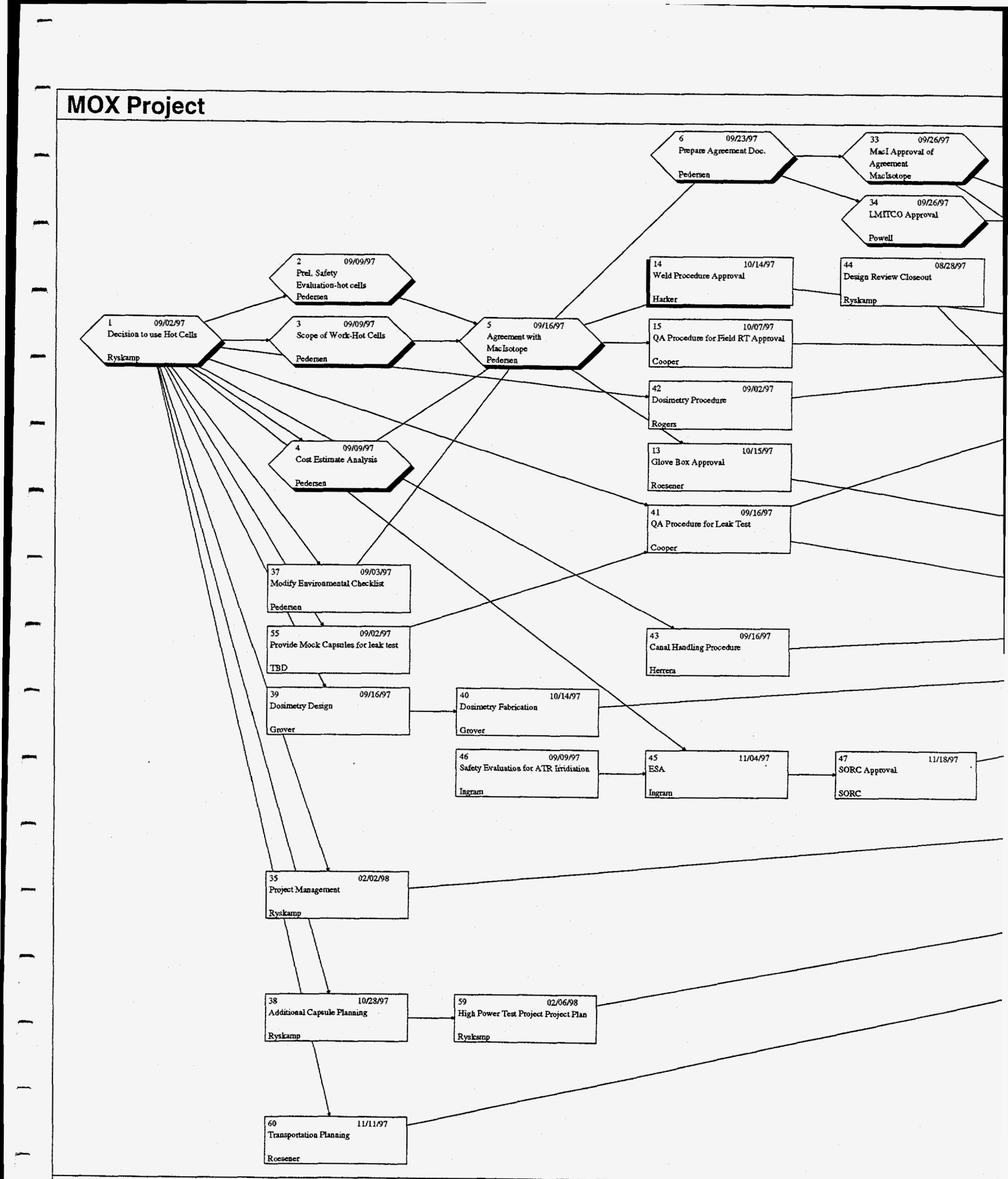





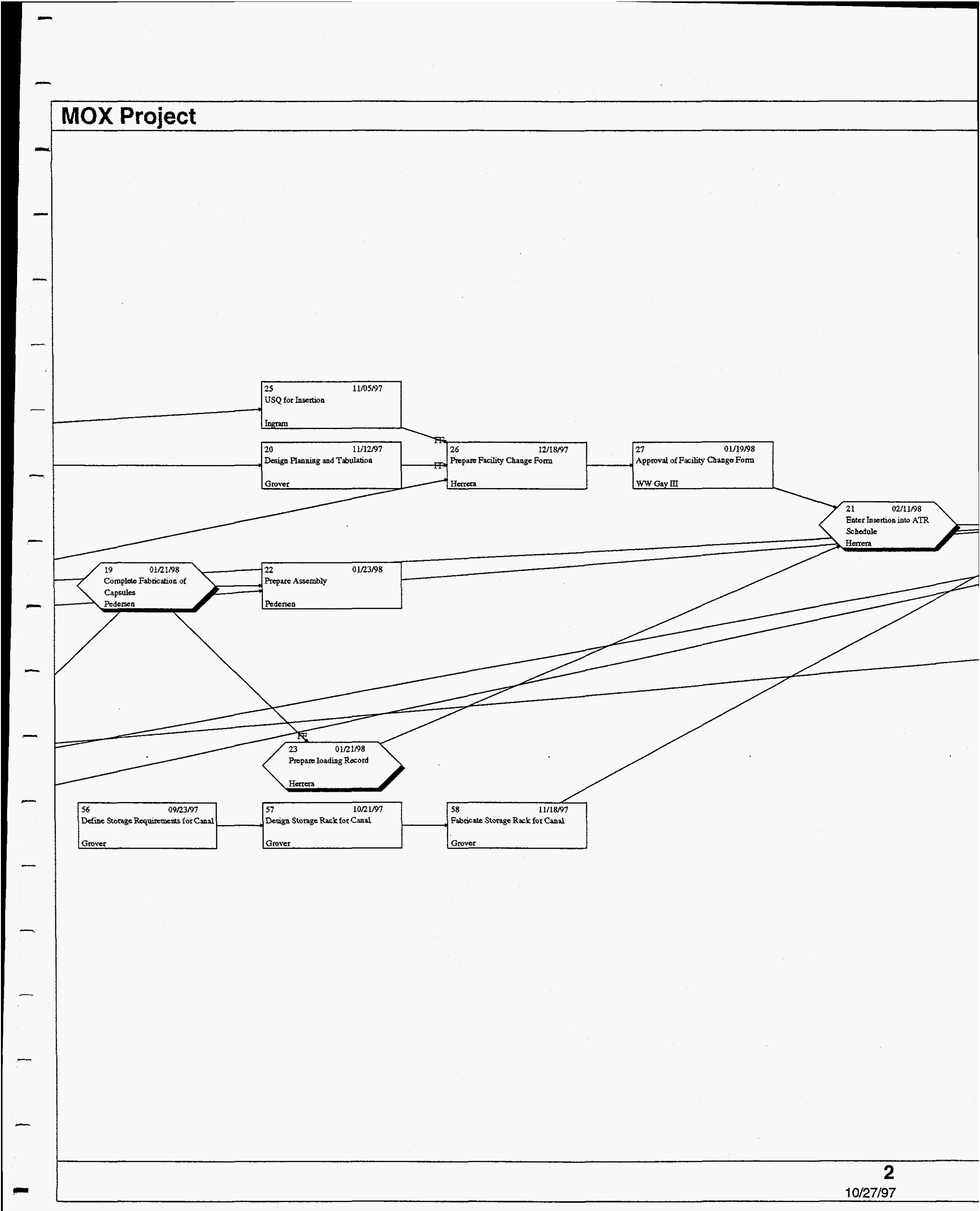

Figure 1. (continued). 
The TRA Hot Cell will receive the Department of Transportation (DOT) certified 30-gallon 6M package with the $2 \mathrm{R}$ insert containing the $13 \mathrm{MOX}$ fuel pin assemblies. The fuel pin assemblies will be stored at the TRA Hot Cell until all capsule assemblies are completed. The shipping drum will used to transfer the completed nine (9) capsule assemblies to the ATR main floor area for test assembly. The empty DOT 30 -gallon $6 \mathrm{M}$ package with the $2 \mathrm{R}$ insert will than be shipped back to LANL upon test assembly insertion.

Material supplied from off-site suppliers will require material composition and fabrication documentation prior to test insertion into the ATR. All material requirements will be documented on the engineering drawings, and the fabrication data package will contain documentation confirming material compositions. Each fuel pin assembly shipped by LANL will be verified through receipt inspection planning per LMITCO Technical Procedure TPR-4960. The hardware supplied by ORNL to complete the capsule assembly will also be verified through receipt inspection, which will include review of material certification documentation. The QA organization will maintain original receipt inspection records as part of the overall receipt inspection documents.

The fuel pin assemblies will be received at the TRA Hot Cell with appropriate Safeguards and Security accountability forms. The fuel pin assemblies will be removed from the shipping container at the TRA Hot Cell prior to loading into the capsule assemblies. The fuel pin accountability reporting will be in compliance with the applicable Material Balance Area (MBA) requirements at TRA (Unirradiated Fissile Material Control Procedure, Standard Practice 10.6.4.6). Specific requirements for record keeping will be documented (Nuclear Materials Control and Record Keeping, Test Reactor Area Hot Cell Operations Standing Directive 21.1.3). The capsule assembly hardware supplied by ORNL will be transported to TRA for receipt and inspection. Shipments of the non-irradiated fuel pins will comply with DOE-ID Order 5480.1, Chapter III, "Safety Requirements for the Packaging of Fissile and other Radioactive Materials".

\subsection{Capsule Assembly}

The change out of capsules cannot be performed inside the reactor vessel, and the entire test assembly will have to be moved through the discharge chute to the canal to perform change out. It is required that the test assembly remain within 45 degrees of vertical at all times so that the individual capsules maintain their orientation inside the basket assembly and do not fall out. The requirement on vertical orientation applies only to the fueled basket assembly, and does not apply to individual capsule assemblies. However, during capsule assembly, inspection and fabrication, the capsule assemblies will need to be "laid down" to perform most of the these activities. Once the capsule assemblies are loaded into the basket assembly, the completed test assembly will be maintained at all times in the required vertical position.

ORNL will supply to INEEL the necessary materials to fabricate three (3) complete sets of simulator capsule assembly hardware, which will meet the same requirements as the hardware to be utilized for assembly of the actual fuel-bearing capsule assemblies. These 3 capsule assemblies will be marked with an $\mathrm{S}$ to identify them as simulators. These simulator assemblies will contain stainless steel simulated pellets and

will be used to obtain experience in the fabrication of fuel pins and capsule assemblies prior to the fabrication of MOX-bearing products. Furthermore, these simulators will be used to develop the necessary techniques for destructive hot cell evaluations at ORNL. The INEEL will receive and inspect the capsule assembly 
hardware from ORNL and the cumpleted fuel pin simulators from LANL. Fabrication and assembly of these capsules will be performed in accordance with the same assembly procedure as the actual capsule assemblies.

All capsule assembly activities will be performed at the TRA Hot Cell with the exception of the radiography, which will be performed at the QA radiography facility, located adjacent to the TRA Hot Cells. The specifics of the capsule assembly will be documented under assembly work release. All necessary assembly hardware will be placed into an approved glove box at the TRA Hot Cell. The glove box will ensure the atmosphere inside the stainless steel capsule to be helium at approximately $1 \mathrm{~atm}$ pressure with a minimum purity level of $99.9 \%$. Helium will be injected into the glove box until the calibrated oxygen measurement indicates less than $<500 \mathrm{ppm}$. The oxygen measurement equipment will be calibrated in accordance with Calibration Program, Management Control Procedure, MCP-2391.

Prior to shutdown, each capsule assembly will be loaded into the test assembly under the capsule assembly work release at the TRA Hot Cell to verify proper fit. The capsule assemblies will be removed and the nine capsule assemblies chosen for the first irradiation cycle will be placed into the 30-gallon package. These nine (9) capsule assemblies will be transferred in the 30-gallon package for final loading into the basket assembly and complete the test assembly at the ATR main floor area during reactor shutdown. Each capsule assembly will be independently verified by $Q A$ for proper loading as required by ORNL drawings. Two (2) additional 10-gallon $6 \mathrm{M}$ packages with $2 \mathrm{R}$ inserts will be used to transfer the remaining four capsule assemblies, each shipping package containing two capsule assemblies. One 10-gallon package will ship the two archive capsule assemblies (archive capsule assemblies, No. 7 and 13) to ORNL in accordance with governing DOE Orders and DOT regulations. The two spare capsule assemblies will be transferred to the ATR-C and stored. The DOT 10-gallon package will function as the approved storage device, ATR Criticality Facility Safety Analysis Report and Technical Specifications, and Nuclear Materials Control and Record Keeping, TRA Hot Cell Operations, Standing Directive 21.1.3., until needed at the ATR canal for loading in the basket assembly following irradiation. The TRA Hot Cell ESA will evaluate the transferring of the completed capsule assemblies to the ATR. The transfers to the ATR from the TRA Hot Cell are intra-TRA transports and will be conducted in accordance with the requirements of TRA Unirradiated Fissile Material Control, TRA Standard Practice 10.6.4.6.

\subsubsection{Inspections}

As part of the overall assembly process, a detailed listing of all inspections including dimensional, cleanliness, receipt documentation, nonconformance, leak tests, radiographic tests, dosimetry inspections, etc. through inspection hold points will be documented in the assembly work release. These inspection hold points are developed based on assembly drawings provided by ORNL. The assembly drawings provide clear direction for QA inspections to be performed. In addition, the capsule assemblies will be loaded as required in the referenced loading pattern described in the ATR Capsule Assembly Loading and Operation Schedule, ORNL/MD/LTR-91. All nonccnformances will be controlled in accordance with Control of Nonconforming Items, Management Control Procedure, MCP-538.

Special handling precautions will be incorporated into the assembly procedure. At no time will Zircaloy components be permitted to come in contact with aluminum. Capsule loading will be performed per the loading drawings supplied by ORNL. Independent verification will be performed by QA. Inspection will be performed by qualified personnel for determination of quality (Inspection and NDE Personnel Certification, 
Management Control Procedure, MCP-535). Dimensional inspections will be performed as required and indicated in the ORNL drawings (Inspection, Management Control Procedure, MCP-2482).

\subsubsection{Welding}

Specific hold points will be established to assure the capsule assembly is assembled per the ORNL drawings. Weld qualification will be completed prior to commencement of capsule assembly. Qualification will be performed on ORNL supplied set-up pieces in the glove box in accordance with The INEEL Weld Manual, and in full compliance with the defined Construction Code (ASME Section III Subsection NB). The set-up pieces will be inspected, and the welder will be qualified following acceptable inspections. Welding will be performed per an approved INEEL Weld Procedure S4.2. Welding of the production capsule will follow the same process parameters and be performed by the same personnel as in the weld qualification. Hold points will be established and documented in the assembly work release. Weld inspections per ASME Section III Class I are required to be performed on the capsules. The capsule assemblies will be filled with a minimum purity of $99.9 \%$ helium and leak tested to assure the limit of $1 \times 10^{-8} \mathrm{STD} \mathrm{CC} / \mathrm{sec}$ is obtained (Leak Test Procedure, Technical Procedure, TPR-4976). Final inspection of the completed capsule assemblies will be performed by QA (Radiographic Examination, Technical Procedure, TPR-4970).

Under the requirements of the Purchase Order: Mixed-Oxide Capsule Assembly: ORNL/MD/LTR-90, two archive fuel pin assemblies (fuel pin assemblies No. 7 and No. 13) will be loaded and sealed into capsule assemblies and then shipped to ORNL. These two capsule assemblies will be shipped to ORNL following the test assembly insertion into ATR, and the two spare completed capsule assemblies will be moved to the ATR-C until needed for initial reloading in the test assembly following appropriate irradiation periods.

\subsection{Documentation}

The completed assembly work release will provide the quality record or history file for each capsule assembly through test assembly insertion into the reactor. The assembly work release will provide documentation in the following areas:

- Hardware and fuel pin receipt inspection

- Hardware and fuel pin cleaning

- Bottom end-cap welding

- $\quad$ Fuel pin loading

- Top end-cap welding

- Nondestructive examinations

- Packaging of the capsule assemblies for transport to ORNL

- Backfill gas analysis, Impurity concentrations in fill gas 
- Material certifications

- Dimensional inspection reports

- Leak test reports

- Nonconformance repiorts.

All test assembly movements, including reactor transfers and insertions, canal transfers and any test assembly changes at the ATR will be documented by reactor operations personnel and are independently verified, (see Section 3.2). In adidition, all data that describe the core neutronic and thermal-hydraulic environment of the test will be available from routine ATR operating measurements. The core neutronic information includes lobe powers of the reactor, positions of the N1, N2, W3, and W4 outer shim control cylinders (OSCC), and positions of the NW neck shims. These data will be obtained from the Reactor Data Acquisition System (RDAS), which performs calculations based on core neutronic instruments, OSCC, and neck shim positions. The thermal-hydraulic information includes the reactor vessel core differential pressure (delta P), core inlet pressure, and core inlet temperature. These data will also be available from the RDAS. This data will be primarily used to perform in-core irradiation calculations. Neutron monitor measurements will be used to verify these results.

Thermal neutron fluence neasurements will allow estimation of the fissile burnup (atom\%) for the fuel pins. Three sets of neutron moritors will be located in the I-hole basket. Data generated from these measurements will be documented and made available through the TRA Radiation Measurements Laboratory (RML) following verification arld validation processes. The neutron monitors will be removed following the specified time frame identified in the Design, Functional, and Operational Requirements for the Advanced Test Reactor Mixed Fuel Irradiation Experiment: ORNL/MD/LTR-76. Two procedures primarily govern the measurement and analyses of the neutron monitors (Routine ATR Neutron Fluence Rate Measurements, RML-13, and Handling/Tracking and Analysis of Neutron Monitors at the RML, RML-25).

Prior to each fuel/operating cycle, INEEL personnel will perform calculations to predict the linear heat generation rate for each capsule assembly as a function of time during the cycle. The results of these calculations will be provided to ORNL prior to cycle startup, and will also be included in the overall documentation for the test. 


\section{REACTOR INSERTION AND REMOVAL}

ATR in-core reactor operations are controlled under specific Test Reactor Area (TRA) procedures. These procedures document the overall activities during reactor operations through shutdown. Routine changes to the core configuration include fuel elements, in-pile experiments, neutron monitors and irradiation tests. During the shutdown period of the reactor, the test assembly will be transferred to operations by the project engineer for insertion into the reactor. Operations will verify the test assembly identification with the reactor loading record information. To support the insertion, additional documentation must be submitted and approved prior to acceptance and insertion of the test assembly into the ATR. When it is anticipated that the planned power level of the North West quadrant (or lobe) power will result in a linear heat generation rate of either less than 6 or greater than $10 \mathrm{~kW} / \mathrm{ft}$ as an average in any fuel pin, approval to continue the irradiation will be obtained from the cognizant ORNL project manager. If the predicted power level is unacceptable, the entire experiment will either be moved to another small I-hole that will provide the acceptable neutronic conditions, be removed from the reactor until an acceptable position can be identified, or be reloaded into another basket assembly with a different neutron shield.

\subsection{Test Irradiation Acceptance}

INEEL Nuclear Operations Quality Assurance personnel cognizant of the ATR QA Program requirements have reviewed the ORNL and LANL QA Programs as they apply to this experiment. Insertion of the test assembly into the ATR is dependent upon INEEL concurrence with the adequacy of these programs. This review and acceptance has been performed and both programs were found to be acceptable.

The ATR Core Safety Assurance Package (CSAP) documents the core safety analysis for each reactor cycle (Core Safety Analysis Preparation, Revision, Scheduling and Use, Standing Directive, SD 11.2.19). The Safety and Operations Review Committee (SORC), an independent safety review committee, is established to provide oversite of any issue or item that has the potential to impact the safe and reliable operation of the facility. An Experimental Safety Analysis (ESA) is a cradle-to-grave review performed to ensure that a proposed test falls within the safety analyses. ESAs are conducted in accordance with ESA Preparation and Approval, Standard Practice, SP 22.2.4. The location and test assembly identification are documented in the ATR Reactor Loading Record (Standard Practice, SD 11.5.4). As part of the overall reactor operations acceptance process, a Facility Change Form (FCF) is required to be completed prior to reactor operations and is performed in accordance with Facility Change Form Preparation and Use, Standard Practice, SP 10.2.2.8. The FCF provides a documentation system that assures all internal reviews have been completed with the ATR Reactor Operations Manager giving final approval. These processes must be followed prior to acceptance of a test for irradiation.

Following Operation's insertion acceptance of the test assembly, in-core reactor loading of the completed assembly will be performed (Experimental Position Insertion and Transfer Checklist, Detailed Operating Procedure, DOP-1R.4). This checklist will document the insertion of the test assembly into the ATR irradiation position as directed by the Reactor Loading Record contained in DOP IR.4. Specific handling and loading instructions may be contained in the Cycle Reference Document, Section 13G (CRD13G) for the capsule irradiation program. Loading changes and shutdown instructions will be placed in this $\mathrm{CRD}$ for special handing instruction, if necessary during the handling of the test assembly. The reactor loading record is attached to DOP-1R.4 for inventory prior to insertion, which is required and documented 
within the DOP. Dual verification insertion is performed versus the reactor position by initialing the reactor loading record. A second inventory will be performed for all affected positions as required in the Reactor Loading Record to ensure the capsule assemblies and baskets are properly "seated". Final signature on the DOP will represent completion of all reactor irradiation experiment changes. These procedures and documents will also provide doclumentation for removal following irradiation. The test assembly will be inserted into position I-24 (Northwest 1.5" I-Hole), as shown in the ATR Core Cross-section Diagram Figure 2.

\subsection{Canal Transfer and Handling}

The irradiated test will be transferred to the ATR canal following removal from the reactor. Canal operations are governed under sjecific procedures for handling these tests (Experiment Handling in the Canal, Operating Maintenance Manual, OMM 7.10.13.1.3). Transfer records will be maintained at the canal (Canal Record Keeping, Operaling Maintenance Manual, OMM 7.10.13.1.5). Transfers from the reactor to the canal and back will be controlled (Reactor/Canal Transfers, Operating Maintenance Manual, OMM 7.10.13.1.2). Instructions related to the removal and replacement of capsule assemblies will be provided to the canal operations personnel by the canal loading record and through the project engineer. The change out of capsules cannot be performed inside the reactor vessel, and the entire test assembly will have to be moved through the discharge chute to the canal to perform change out. It is critical that the test assembly remain within $\mathbf{4 5}$ degrees of vertical at all times so that the individual capsules maintain their orientation inside the basket assembly. The canal handling and discharge instructions will provide the necessary direction for using the tools to ensure the basket reinains in the vertical position during in-vessel and canal handling. ORNL will provide a small MOX capsule assembly carrier that can accommodate the thirteen (13) capsule assemblies. If additional carrier capability is needed, a second identical carrier will be supplied. ORNL will provide, with INEEL concurrence of the design, tooling necessary to manipulate capsules during installation and removal from the basket. The MOX capsule assembly carrier will need to be analyzed to assure criticality concerns are addressed, during normal or off-normal operations.

The neutron dosimetry will be removed from the test assembly after the first cycle of operation and analyzed to compare with the neutronic analyses. Neutron dosimetry will include nickel wires (fast neutron) and cobalt aluminum wires (thermal neutron). The neutron dosimetry analysis will normally require $a$ one to two week decay time to limit radiation handing exposures. New dosimetry will be loaded into the test assembly for the second cycle of irradiation. Schedules for further neutron dosimetry removal will be determined after analysis of the first neutron dosimetry set and upon agreement between ORNL and NEEL, but as a minimum, the neutron dosimetry will be changed when the test assembly/capsule configuration is altered. Once the test assembly is transferred to the canal, the capsule assemblies and required neutron dosimetry will be removed in accordance with the instructions provided and documented in the canal loading records. The neutron dosimetry will be removed with a special removal tool designed by INEEL engineering staff. Following completion of the removal and insertion of new neutron dosimetry, the test assembly will be transferred to the reactor in-coris operations personnel for insertion into the reactor irradiation position. The neutron dosimetry will be analyzed per $\mathbb{R M L}$ specific procedures following removal, and appropriate decay time. The flux wires will be rernoved by the canal operators (Experiment Handling in the Canal, Operating Maintenance Manual, OMM 7.10.13.1.3), and the results will be provided to the project engineer when completed. 
Two (2) capsule assemblies will be removed after reaching approximately $8 \mathrm{GWD} / \mathrm{MT}$. Two (2) will be removed at $20 \mathrm{GWD} / \mathrm{MT}$. The remaining will be removed at $30 \mathrm{GWD} / \mathrm{MT}$ average burnup, corresponding to approximately $9,24,36$ months, respectively. After at least one pin, with the identified capsule assembly for early removal reaches a burnup level of $8 \mathrm{GWD} / \mathrm{MT}$, the experiment assembly will be removed from the reactor, and the two chosen capsules will be removed. The two (2) spares will be placed into the basket assembly along with seven (7) of the original nine (9). Two additional capsule assemblies will be removed in a similar manner at the shutdown following achievement of 20 GWD/MT in one or more of the capsule assemblies. Non-fueled simulator stainless steel capsule assemblies may then be inserted in some of the positions supplied by ORNL. Irradiation will continue until one or more of the capsules has reached $30 \mathrm{GWD} / \mathrm{MT}$. The loading records and ESA will need to address the potential inclusion of non-fueled simulator assemblies in the test assembly. 


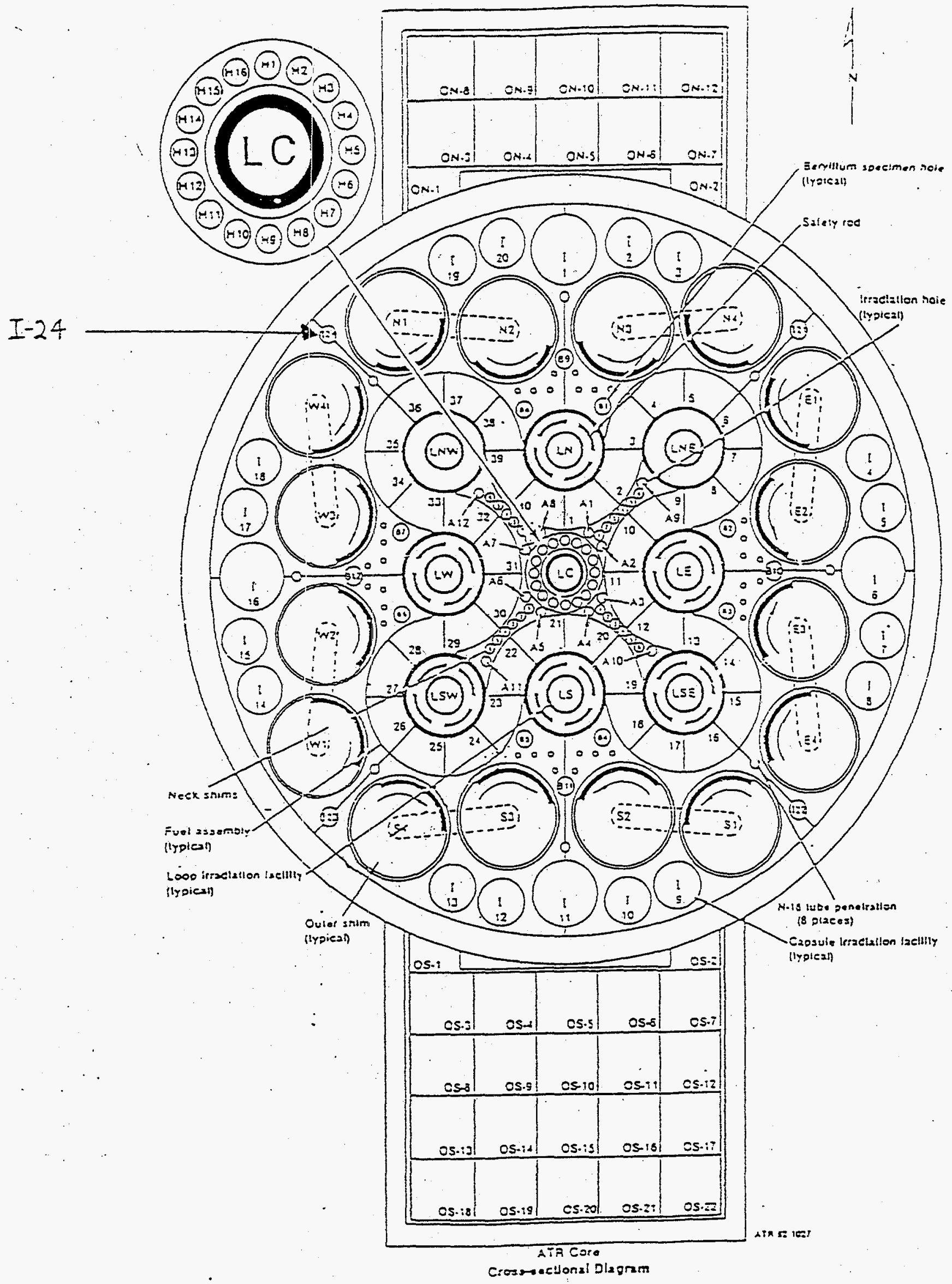

Figure 2. ATR core cross-sextion diagram. 


\section{CAPSULE SHIPMENTS}

All of the irradiated fuel will be shipped to ORNL for post-irradiation examinations (PIE). The transportation tasks are divided into three sub-tasks: the assembly basket and empty capsules to INEEL, shipment of the fuel pins to the ATR, and shipment of irradiated capsules to ORNL for examination. The empty capsules and assembly basket will be packaged and shipped commercially from ORNL to INEEL. ORNL will lead the development of a Transportation Plan that describes these shipments, identifies the candidate shipping containers, identifies the radioactive materials to be shipped, and describes the responsibility of each laboratory. The irradiated fuel pin shipments from the INEEL to ORNL will be coordinated by the INEEL.

\subsection{ORNL Unirradiated Archive Capsule Assemblies}

Shipments of the non-irradiated capsule assemblies back to ORNL will comply with DOE-ID Order 5480.1, Chapter III, "Safety Requirements for the Packaging of Fissile and other Radioactive Materials". The two (2) archive capsule assemblies (archive capsule assemblies, No. 7 and 13) will be shipped back to ORNL, and the remaining 2 spare capsule assemblies will be moved to the ATR-C under Safeguards and Security controls until needed at the ATR canal for loading in the basket assembly following irradiation. The transfer to ATR-C and the shipment to ORNL will involve using a 10 -gallon $6 \mathrm{M}$ package with a $2 \mathrm{R}$ insert.

\subsection{Irradiated Capsule Assembly}

Shipping packages that are compatible with the ATR canal and ORNL's hot cells have been identified. The ESA is required to review activities involving canal handling and packaging at the ATR facility. This assures the ESA addresses the identification of the cask for off-site shipments in the cradle-to-grave approach. Currently the candidate casks to be used for transporting the irradiated capsules are the General Electric 100 and 2000 series casks. For the first and second shipments of two (2) irradiated capsules to ORNL, the GE-100 cask will be used. Loading and unloading the GE-100 series cask will be performed under an approved DOP (Loading and/or Unloading the General Electric 100 Series Cask, Detailed Operating Procedure, DOP 4.8.36).

If the GE-2000 cask is used to transport the final seven (7) irradiated capsule assemblies, the two simulator capsule assemblies and other irradiated hardware, the cask will be used in accordance with DOP 4.8.4, Loading/Unloading the General Electric 2000 Series Cask. The type of cask will determine if revisions will be required to existing DOP's for previously handled casks at the canal, or if new DOP's will be required if the cask has not been previously used at ATR. Once ORNL and INEEL agree upon the chosen casks, the INEEL will determine if additional revisions to existing DOP's will be needed or if a new DOP will be required. 


\section{REFERENCES}

1. B. S. Cowell and S. A. Hodge, Fissile Materials Disposition Program Light Water Reactor Mixed Oxide Fuel Irradiation Test Project Plan, ORNL/MD/LTR-78, Lockheed Martin Energy Research Corp., Oak Ridge National Laboratory, July 1997.

2. 10 CFR 830.120 , Quality Assurance Requirements, Latest version.

3. B. S. Cowell, ATR Capsu'e Assembly Loading and Operation Schedule, ORNL/MD/LTR-91, Lockheed Martin Energy Research Corp., Oak Ridge National Laboratory, September 1997.

4. B. S. Cowell, Purchase Order: Mixed-Oxide Capsule Assemblies: ORNL/MD/LTR-90, Lockheed Martin Energy Research Corp., Oak Ridge National Laboratory, August 1997.

5. J. M. Ryskamp, Project Management Plan for INEEL Portion of the Mixed Oxide Fuel Irradiation Test Project, PLN-194, Lockheed Martin Idaho Technologies Corp., Idaho National Engineering and Environmental Laboratory, March 1997.

6. L. S. Dickerson and M. J. Welch, Fresh Fuel Test Shipment Plan for LWR MOX Fuel Irradiation Test Project, ORNL/MD/LTR-87, Lockheed Martin Energy Research Corp., Oak Ridge National Laboratory, September 1997.

7. K. R. Thoms, Design, Functional, and Operational Requirements for the Advanced Test Reactor Mixed Oxide Fuel Irradiction Experiment, ORNL/MD/LTR-76, Lockheed Martin Energy Research Corp., Oak Ridge National Laboratory, Rev. 01, September 1997.

8. L. S. Dickerson, Irradiated Test Fuel Transportation Plan for LWR MOX Fuel Irradiation Test Project, ORNL/MD/LTR-101, Lockheed Martin Energy Research Corp., Oak Ridge National Laboratory, to be published.

9. Lockheed Martin Energy Research Corp., Oak Ridge National Laboratory, Drawing X2E801214A001, June 1997, Rev. 0, ATR FMDP Experiment ATR Basket Assembly.

10. Lockheed Martin Energy Research Corp., Oak Ridge National Laboratory, Drawing X2E801214A002, June 1997, Rev. 0, ATR FMDP Experiment FMDP Experiment Basket Assembly.

11. Lockheed Martin Energy Research Corp., Oak Ridge National Laboratory, Drawing X2E801214A003, June 1997, Rev. 0, ATR FMDP Experiment ATR FMDP Experiment Basket ATR Basket Center Section (3 Pages).

12. Lockheed Martin Energy lResearch Corp., Oak Ridge National Laboratory, Drawing X2E801214A004, June 1997, Rev. 0, ATR FMDP Experiment FMDP Experiment Basket ATR Basket Outer Sleeve. 
13. Lockheed Martin Energy Research Corp., Oak Ridge National Laboratory, Drawing X2E801214A005, June 1997, Rev. 0, ATR FMP Experiment Basket Outer Sleeve Outer Sleeve Support.

14. Lockheed Martin Energy Research Corp., Oak Ridge National Laboratory, Drawing X2E801214A006, June 1997, Rev. 0, ATR FMDP Experiment FMDP Experiment Basket Sleeve Support Housing.

15. Lockheed Martin Energy Research Corp., Oak Ridge National Laboratory, Drawing X2E801214A007, June 1997, Rev. 0, ATR FMDP Experiment ATR FMDP Experiment Basket Sleeve Support Web.

16. Lockheed Martin Energy Research Corp., Oak Ridge National Laboratory, Drawing X2E801214A008, June 1997, Rev. 0, ATR FMDP Experiment ATR FMDP Fuel Pin Fuel Pellet Installer.

17. Lockheed Martin Energy Research Corp., Oak Ridge National Laboratory, Drawing X2E801214A009, June 1997, Rev. 0, ATR FMDP Experiment ATR FMP Fuel Pellet ATR Fuel Pellet.

18. Lockheed Martin Energy Research Corp., Oak Ridge National Laboratory, Drawing X2E801214A010, June 1997, Rev. 0, ATR FMDP Experiment ATR FMDP Capsule Assembly ATR Capsule Assembly.

19. Lockheed Martin Energy Research Corp., Oak Ridge National Laboratory, Drawing X2E801214A011, June 1997, Rev. 0, ATR Capsule Experiment ATR FMDP Capsule ATR Capsule Body.

20. Lockheed Martin Energy Research Corp., Oak Ridge National Laboratory, Drawing X2E801214A012, June 1997, Rev. 0, ATR FMDP Experiment ATR FMDP Capsule Capsule Outer Tube.

21. Lockheed Martin Energy Research Corp., Oak Ridge National Laboratory, Drawing X2E801214A013, June 1997, Rev. 0, ATR FMDP Experiment ATR FMDP Capsule Capsule Bottom End Cap.

22. Lockheed Martin Energy Research Corp., Oak Ridge National Laboratory, Drawing X2E801214A014, June 1997, Rev. 0, ATR FMDP Experiment ATR FMDP Fuel Pin Fuel Pin Inner Tube.

23. Lockheed Martin Energy Research Corp., Oak Ridge National Laboratory, Drawing X2E801214A015, June 1997, Rev. 0, ATR FMDP Experiment ATR FMDP Capsule Capsule Top End Cap (2 Pages).

24. Lockheed Martin Energy Research Corp., Oak Ridge National Laboratory, Drawing X2E801214A016, June 1997, Rev. 0, ATR FMDP Experiment ATR FMDP Capsule Helical Compression Spring.

25. Lockheed Martin Energy Research Corp., Oak Ridge National Laboratory, Drawing X2E801214A017, June 1997, Rev. 0, ATR FMDP Experiment ATR FMDP Experiment Fuel Pin ATR Fuel Pin Assembly.

26. Lockheed Martin Energy Research Corp., Oak Ridge National Laboratory, Drawing X2E801214A018, June 1997, Rev. 0, ATR FMDP Experiment ATR FMDP Fuel Pin Fuel Pin Bottom End Cap.

27. Lockheed Martin Energy Research Corp., Oak Ridge National Laboratory, Drawing X2E801214A019, June 1997, Rev. 0, ATR FMDP Experiment ATR FMDP Fuel Pin Fuel Pin Top End Cap. 
28. Lockheed Martin Energy Research Corp., Oak Ridge National Laboratory, Drawing X2E801214A020, September 1997, ATR FMDP Experiment ATR FMPD Experiment Fuel Pin ATR Fuel Pin Flow Test Dummy.

29 Lockheed Martin Idaho Technologies Corp., Idaho National Engineering and Environmental Laboratory, Drawing 501:360, 10/3/97, ATR MOX TEST FLUX MONITOR ASSEMBLY.

30. Lockheed Martin Idaho Technologies Corp., Idaho National Engineering and Environmental Laboratory, Drawing 501361, 10/3/97, ATR MOX TEST FLUX MONITOR SUPPORT DISC.

31. Lockheed Martin Idaho Technologies Corp., Idaho National Engineering and Environmental Laboratory, Drawing 501362, 10/3/97, ATR MOX TEST FLUX MONITOR HOLDER. 